\title{
Anti-Obesity and Anti-Diabetic Effects of Acacia Polyphenol in Obese Diabetic KKAy Mice Fed High-Fat Diet
}

\author{
Nobutomo Ikarashi, Takahiro Toda, Takehiro Okaniwa, Kiyomi Ito, Wataru Ochiai, \\ and Kiyoshi Sugiyama
}

Department of Clinical Pharmacokinetics, Hoshi University, Tokyo, Japan

Correspondence should be addressed to Kiyoshi Sugiyama, sugiyama@hoshi.ac.jp

Received 13 October 2009; Accepted 12 December 2009

Copyright (C 2011 Nobutomo Ikarashi et al. This is an open access article distributed under the Creative Commons Attribution License, which permits unrestricted use, distribution, and reproduction in any medium, provided the original work is properly cited.

\begin{abstract}
Acacia polyphenol (AP) extracted from the bark of the black wattle tree (Acacia meansii) is rich in unique catechin-like flavan3-ols, such as robinetinidol and fisetinidol. The present study investigated the anti-obesity/anti-diabetic effects of AP using obese diabetic KKAy mice. KKAy mice received either normal diet, high-fat diet or high-fat diet with additional AP for 7 weeks. After the end of administration, body weight, plasma glucose and insulin were measured. Furthermore, mRNA and protein expression of obesity/diabetic suppression-related genes were measured in skeletal muscle, liver and white adipose tissue. As a result, compared to the high-fat diet group, increases in body weight, plasma glucose and insulin were significantly suppressed for AP groups. Furthermore, compared to the high-fat diet group, mRNA expression of energy expenditure-related genes (PPAR $\alpha$, PPAR $\delta$, CPT1, ACO and UCP3) was significantly higher for AP groups in skeletal muscle. Protein expressions of CPT1, ACO and UCP3 for AP groups were also significantly higher when compared to the high-fat diet group. Moreover, AP lowered the expression of fat acid synthesis-related genes (SREBP-1c, ACC and FAS) in the liver. AP also increased mRNA expression of adiponectin and decreased expression of TNF- $\alpha$ in white adipose tissue. In conclusion, the anti-obesity actions of AP are considered attributable to increased expression of energy expenditure-related genes in skeletal muscle, and decreased fatty acid synthesis and fat intake in the liver. These results suggest that AP is expected to be a useful plant extract for alleviating metabolic syndrome.
\end{abstract}

\section{Introduction}

Acacia is an evergreen tree belonging to the genus Acacia in the family legume, and is widely found in the Australian and African continents. The extract of Acacia catechu duramen is called gambir, and has long been used as an astringent and anti-bacterial to treat stomatitis and diarrhea in Japan and China. Studies have also reported that the powdered seeds of Acacia catechu and Acacia milanoxylon exhibit hypoglycemic actions by increasing insulin secretion in nondiabetic rats and rabbits $[1,2]$. Furthermore, in Europe, acacia polyphenol (AP) extracted from the bark of the black wattle tree (Acacia meansii) has been used to eliminate wine sediment. Australian aborigines also eat the young leaves and beans of Acacia mollissima.

$\mathrm{AP}$ is rich in unique catechin-like flavan-3-ols, such as robinetinidol and fisetinidol [3-6]. In recent years, polyphenols have been reported to possess various pharmacological actions, including anti-obesity actions [7-9], anti-diabetic actions [10-12], anti-cancer actions $[13,14]$ and anti-allergic actions [15]. While polyphenol-rich AP may possess various pharmacological actions like other polyphenols, no studies have yet clarified the pharmacological actions of AP.

In the present study, to investigate the anti-obesity and anti-diabetic actions of AP, a high-fat diet was administered to KKAy mice, an obese type-II diabetes model, to induce severe obesity and diabetes. The effects of AP on obesity and diabetes were then studied. To elucidate the mechanisms underlying the suppression of obesity and diabetes, the effects of AP on the expression of genes related to obesity and diabetes suppression in skeletal muscle, liver and white adipose tissue were investigated.

\section{Materials and Methods}

2.1. Hot Water Extraction from Acacia Bark. AP was donated by Mimozax Co., Ltd. (Hiroshima, Japan), and was prepared 
according to the methods reported by Cutting [16]. Briefly, the powdered bark of South African A. mollissima was pulverized and extracted for $30 \mathrm{~min}$ in a 10 -fold volume of hot water $\left(100^{\circ} \mathrm{C}\right)$ and then dried using a spray drier. The polyphenol content of the present product as measured by the Stiasny reaction was $79.0 \%$ [17-19]. Average molecular weight of AP is $1250(300-3000)$ [20, 21], and robinetinidol and fisetinidol are the major ingredients [3-6].

2.2. Materials. Powdered regular low-fat diet (LF) (10\% lard, D12450B) and powdered high-fat diet (HF) (60\% lard, D12492) were purchased from Research Diets (New Brunswick, NJ, USA). Primers were purchased from Invitrogen (Tokyo, Japan). The ECL Plus Western Blotting Detection System was purchased from GE Healthcare (Chalfont St Giles, UK). Anti-rabbit ACO antibody and anti-rabbit UCP3 antibody were purchased from Abcam (Cambridge, UK). Anti-rabbit CPT1 antibody was purchased from Santa Cruz Biotechnology (Santa Cruz, CA, USA). Anti-rabbit $\beta$ actin antibody was purchased from BioLegend (San Diego, CA, USA). Anti-rabbit IgG (whole molecule) peroxidase conjugate was purchased from Sigma-Aldrich (St Louis, MO, USA). All other reagents were of the highest commercially available grade.

2.3. Animals, Diets and Treatment. Male KKAy mice (5weeks old) were purchased from Clea Japan (Tokyo, Japan). Each mouse was caged separately and kept at room temperature $\left(22 \pm 1^{\circ} \mathrm{C}\right)$ and $55 \pm 10 \%$ humidity with $12 \mathrm{~h}$ of light (artificial illumination: 08:00-20:00). Mice that had been acclimatized for 1 week were divided into four groups. Each group was provided with ad libitum access to either LF, HF, HF containing 2.5\% (w/w) AP (HF/AP 2.5\%) or HF containing $5.0 \%(\mathrm{w} / \mathrm{w})$ AP (HF/AP $5.0 \%)$ for 7 weeks. Food intake was measured once weekly. Following this feeding period, after $17 \mathrm{~h}$ of fasting, a blood sample was collected using heparin from the abdominal vena cava under diethyl ether-induced anesthesia. The liver, white adipose tissue (around the testes, retroperitoneum and kidney) and skeletal muscle were also removed and placed in either neutral-buffered formalin or liquid nitrogen. The present study was conducted in accordance with the Guiding Principles for the Care and Use of Laboratory Animal, as adopted by the Committee on Animal Research at Hoshi University.

2.4. Blood Analysis. Blood samples were centrifuged ( $1000 \mathrm{~g}$ for $15 \mathrm{~min}$ at $4^{\circ} \mathrm{C}$ ), and plasma stored at $-80^{\circ} \mathrm{C}$ until assay. Plasma glucose concentrations were enzymatically quantified using a Glucose CII Test (Wako Pure Chemical Industries, Osaka, Japan). Plasma insulin concentrations were measured according to the protocol described by the manufacturer of the Mouse Insulin ELISA Kit (Shibayagi, Gunma, Japan). Plasma glutamate oxalacetate transaminase (GOT) and glutamate pyruvate transaminase (GPT) concentrations were quantified using Transaminase CII Test (Wako Pure Chemical Industries).
2.5. Homeostasis Model Assessment of Insulin Resistance Index. Homeostasis model assessment of insulin resistance (HOMA-IR), an index of insulin resistance, was calculated according to the following equation using fasting insulin and glucose concentrations [22]:

$$
\begin{aligned}
\text { HOMA-IR }= & \text { fasting insulin }\left(\mu \mathrm{U} \mathrm{ml}^{-1}\right) \\
& \times \text { fasting glucose }\left(\mathrm{mmoll}^{-1}\right) / 22.5 .
\end{aligned}
$$

2.6. Measurement of Liver Triglyceride/Cholesterol Content. Liver triglyceride and cholesterol content were measured as described previously $[23,24]$. Briefly, a portion $(100 \mathrm{mg})$ of liver tissue was homogenized in phosphate buffer saline $(\mathrm{pH} 7.4,1 \mathrm{ml})$. The homogenate $(0.2 \mathrm{ml})$ was extracted with isopropyl alcohol $(1 \mathrm{ml})$, and the extract was analyzed using a Triglyceride E-Test (Wako Pure Chemical Industries) to determine liver triglyceride content. The homogenate $(0.2 \mathrm{ml})$ was extracted with chloroform-methanol $(2: 1$, $1 \mathrm{ml}$ ), and the extract was concentrated under a nitrogen stream. The residue was dissolved in isopropyl alcohol and analyzed using a Cholesterol E-Test (Wako Pure Chemical Industries).

\subsection{Preparation of Slide for Histopathology}

2.7.1. Hematoxylin-Eosin Staining. Liver and epididymal fat were fixed in 10\% neutral-buffered formalin. After trimming the tissues, liver and epididymal fat were embedded in paraffin using a tissue processor. Sections were taken in 3-4 $\mu \mathrm{m}$ thicknesses, and stained with HE solution for microscopy. Average surface area for epididymal white adipocytes was measured using Image J software (National Institute of Mental Health, Bethesda, MD, USA) [25, 26].

2.7.2. Oil red O Staining. After frozen liver sections about $7 \mu \mathrm{m}$ thick were prepared using a cryostat apparatus, oil red $\mathrm{O}$ staining was conducted for microscopy.

2.8. RNA Preparation from Tissue Samples. RNA was extracted from about $50 \mathrm{mg}$ of frozen skeletal muscle using TRI reagent. RNA was extracted from about $15 \mathrm{mg}$ of frozen liver using the RNeasy Mini Kit. RNA was extracted from about $75 \mathrm{mg}$ of frozen epididymal white adipose tissue using the RNeasy Lipid Tissue Mini Kit. RNA extraction was performed according to the protocol for the TRI Reagent, RNeasy Mini Kit and RNeasy Lipid Tissue Mini Kit. The resulting solution was diluted 50-fold using TE buffer, and purity was confirmed and RNA concentration $\left(\mu \mathrm{g} \mathrm{ml}^{-1}\right)$ was calculated by measuring absorbance at 260 and $280 \mathrm{~nm}$ using a U-2800 spectrophotometer (Hitachi High Technologies, Tokyo, Japan).

2.9. Real-time RT-PCR. A high-capacity cDNA synthesis kit was used to synthesize cDNA from $1 \mu \mathrm{g}$ of RNA. TE buffer was used to dilute the cDNA 20-fold to prepare cDNA TE buffer solution. The expression of target genes 
TAble 1: Primer sequences of mouse mRNA.

\begin{tabular}{llllc}
\hline Target & Accession number & Forward primer $\left(5^{\prime}-3^{\prime}\right)$ & Reverse primer $\left(5^{\prime}-3^{\prime}\right)$ & Amplicon size (bp) \\
\hline PPAR $\alpha$ & NM_011144 & GTACGGTGTGTATGAAGCCATCTT & GCCGTACGCGATCAGCAT & 76 \\
PPAR $\delta$ & NM_011145 & GCCATATTCCCAGGCTGTC & CAGCACAAGGGTCATCTGTG & 102 \\
CPT1 & NM_013495 & GTGACTGGTGGGAGGAATAC & GAGCATCTCCATGGCGTAG & 83 \\
ACO & NM_015729 & GTGCAGCTCAGAGTCTGTCCAA & TACTGCTGCGTCTGAAAATCCA & 112 \\
UCP3 & NM_009464 & CCAGAGCATGGTGCCTTCGCT & CTCGTGTCAGCAGCAGTG & 84 \\
GLUT4 & NM_009204 & GGAAGGAAAAGGGCTATGCTG & TGAGGAACCGTCCAAGAATGA & 115 \\
SREBP-1c & NM_011480 & ACGGAGCCATGGATTGCACA & AAGGGTGCAGGTGTCACCTT & 278 \\
ACC & NM_133360 & ATGGGCGGAATGGTCTCTTTC & TGGGGACCTTGTCTTCATCAT & 148 \\
FAS & NM_007988 & TGCTCCCAGCTGCAGGC & GCCCGGTAGCTCTGGGTGTA & 107 \\
PPAR $\gamma$ & NM_011146 & CCAGAGCATGGTGCCTTCGCT & CAGCAACCATTGGGTCAGCTC & 241 \\
LPL & NM_008509 & CCACAGCAGCAAGACCTTC & AGGGCGGCCACAAGTTTG & 87 \\
Adiponectin & NM_009605 & GAGATGCAGGTCTTCTTGGTC & GCTCTCCTTTCCTGCCAG & 105 \\
TNF- $\alpha$ & NM_013693 & AAGCCTGTAGCCCACGTCGTA & GGCACCACTAGTTGGTTGTCTTTG & 122 \\
$\beta$-Actin & NM_007393 & GAGCGCAAGTACTCTGTGTG & CGGACTCATCGTACTCCTG & 97 \\
\hline
\end{tabular}

$\operatorname{PPAR} \alpha$, peroxisome proliferator-activated receptor $\alpha$; $\operatorname{PPAR} \delta$, peroxisome proliferator-activated receptor $\delta$; CPT1, carnitine palmitoyl-transferase1; ACO, acyl CoA oxidase; UCP3, uncoupling protein3; GLUT4, glucose transporter4; SREBP-1c, sterol regulatory element-binding protein-1c; ACC, acetyl-CoA carboxylase; FAS, fatty acid synthase; PPAR $\gamma$, peroxisome proliferator-activated receptor $\gamma$; LPL, lipoprotein lipase; TNF- $\alpha$, tumor necrosis factor- $\alpha$.

was detected by preparing primers listed in Table 1 and performing real-time RT-PCR. To each well of a Multiplate PCR Plates 96-well clear (Bio-Rad Laboratories), $25 \mu \mathrm{l}$ of iQ SYBR Green Supermix, $3 \mu$ l of forward primer of target gene $\left(5 \mathrm{pmol} \mu \mathrm{l}^{-1}\right), 3 \mu \mathrm{l}$ of reverse primer $\left(5 \mathrm{pmol} \mu \mathrm{l}^{-1}\right), 4 \mu \mathrm{l}$ of cDNA TE buffer solution and $15 \mu \mathrm{l}$ of RNase-free water were added. With regard to $\beta$-actin, a housekeeping gene, $4 \mu \mathrm{l}$ of a cDNA TE buffer solution that was prepared by diluting above-mentioned solution 20 -fold using TE buffer was used. Denaturation temperature was set at $95^{\circ} \mathrm{C}$ for $15 \mathrm{~s}$, annealing temperature at $56^{\circ} \mathrm{C}$ for $30 \mathrm{~s}$ and elongation temperature at $72^{\circ} \mathrm{C}$ for $30 \mathrm{~s}$. Fluorescence intensity of the amplification process was monitored using the My $\mathrm{iQ}^{\mathrm{TM}}$ Single Color Real-time RT-PCR Detection System (Bio-Rad Laboratories). mRNA expressions were normalized using $\beta$ actin. All mRNA expressions were expressed in relation to the average expression of the LF group (100\%).

2.10. Western Blotting Analysis. Leg muscle (100 mg) was homogenized using dissecting buffer $(0.3 \mathrm{M}$ sucrose, $25 \mathrm{mM}$ imidazole, $1 \mathrm{mM}$ EDTA, pH 7.2, containing $8.5 \mu \mathrm{M}$ leupeptin, and $1 \mathrm{mM}$ phenylmethylsulfonyl fluoride), and the homogenates were centrifuged at $500 \mathrm{~g}$ for $10 \mathrm{~min}$ at $4^{\circ} \mathrm{C}$ $[27,28]$. Total protein content in the supernatants was determined by the Lowry method [29] using bovine serum albumin as a standard.

Electrophoresis was performed using the method described by Laemmli [30]. Using the loading buffer (84 $\mathrm{mM}$ Tris, $20 \%$ glycerol, $0.004 \%$ bromophenol blue, $\mathrm{pH}$ $6.3,4.6 \%$ SDS and 10\% 2-mercaptoethanol), protein was diluted 2-fold, boiled for $5 \mathrm{~min}$ and applied to $12.5 \%$ polyacrylamide gel (ATTO Corp., Tokyo, Japan). After electrophoresis, the isolated proteins were transferred to a PVDF membrane (ATTO Corp.) using CompactBLOT
(AE-7500, ATTO Corp.). After blocking for $1 \mathrm{~h}$ using 1.0\% skim milk, the resulting membrane was reacted for $1 \mathrm{~h}$ at room temperature with anti-rabbit CPT1 antibody $(1: 100)$, ACO antibody $(1: 200)$, UCP3 antibody $(1: 1,000)$ or $\beta$ actin antibody $(1: 200)$. After washing the membrane using TBS-TWEEN (Tris- $\mathrm{HCl} 20 \mathrm{mM}, \mathrm{NaCl} 137 \mathrm{mM}$ and Tween $200.1 \%$, pH 7.6), the resulting membrane was reacted for $1 \mathrm{~h}$ at room temperature with anti-rabbit IgG peroxidase conjugate. After washing, the membrane was reacted with the ECLplus detection reagent and visualized with an LAS-3000 mini luminoimage analyzer (Fuji Film, Tokyo, Japan). Protein levels were normalized against $\beta$-actin. All protein expressions are given as percentages compared to the LF group (100\%).

2.11. Statistical Analysis. Numerical data are expressed as means \pm standard deviation. The significance of differences was examined using ANOVA, followed by Tukey's test. Values of $P<.05$ were considered significant.

\section{Results}

3.1. Body Weight and Visceral Fat Accumulation. During the 7-week experimental period, food intake was measured once weekly. Mean energy intake was significantly higher for the HF group than for the LF group. No significant difference existed in energy intake between the HF, HF/AP 2.5\% and HF/AP 5.0\% groups (Table 2).

At the end of administration, body weight was significantly higher for the HF group than for the LF group. AP administration significantly suppressed HF-induced body weight increases. In particular, the degree of body weight increase was comparable between the HF/AP 5.0\% and LF groups (Table 2). 
TABLE 2: Body weight gain, and plasma and hepatic biochemistry of mice fed on the experimental diets for 7 weeks.

\begin{tabular}{|c|c|c|c|c|}
\hline & LF & $\mathrm{HF}$ & HF/AP $2.5 \%$ & HF/AP 5.0\% \\
\hline Food intake (g/mouse/day) & $5.1 \pm 0.9$ & $4.5 \pm 0.6$ & $4.6 \pm 0.5$ & $4.4 \pm 0.5$ \\
\hline Energy intake (kcal/mouse/day) & $19.4 \pm 3.6$ & $23.3 \pm 3.2^{*}$ & $23.5 \pm 2.8^{*}$ & $22.0 \pm 2.9^{*}$ \\
\hline Pre-diet body weight $(\mathrm{g})$ & $31.3 \pm 1.2$ & $30.9 \pm 1.1$ & $31.5 \pm 1.6$ & $31.1 \pm 1.0$ \\
\hline Post-diet body weight (g) & $39.7 \pm 2.4$ & $51.4 \pm 2.5^{* *}$ & $45.7 \pm 4.7^{* *, \# \#}$ & $39.5 \pm 1.6^{\# \#}$ \\
\hline Body weight gain (g) & $8.4 \pm 1.9$ & $20.5 \pm 2.0^{* *}$ & $14.2 \pm 4.3^{* *, \# \#}$ & $8.4 \pm 1.9^{\# \#}$ \\
\hline Whole WAT (g) & $3.14 \pm 0.60$ & $4.66 \pm 0.34^{* *}$ & $4.00 \pm 0.35^{* *, \# \#}$ & $3.37 \pm 0.54^{\# \#}$ \\
\hline Epididymal WAT (g) & $1.63 \pm 0.23$ & $1.97 \pm 0.21^{*}$ & $1.77 \pm 0.22^{\#}$ & $1.70 \pm 0.22^{\#}$ \\
\hline Retroperitoneal WAT (g) & $0.96 \pm 0.28$ & $1.57 \pm 0.21^{* *}$ & $1.31 \pm 0.19^{* *}$ & $0.94 \pm 0.19^{\# \#}$ \\
\hline Perirenal WAT $(\mathrm{g})$ & $0.66 \pm 0.14$ & $1.35 \pm 0.19^{* *}$ & $0.91 \pm 0.19^{*, \# \#}$ & $0.76 \pm 0.23^{\# \#}$ \\
\hline Liver weight $(\mathrm{g})$ & $1.85 \pm 0.22$ & $3.27 \pm 0.44^{* *}$ & $1.83 \pm 0.40^{\# \#}$ & $1.26 \pm 0.13^{* *, \# \#}$ \\
\hline Liver triglyceride $\left(\mathrm{mg} \mathrm{g}^{-1}\right.$ liver $)$ & $78.0 \pm 13.8$ & $156.5 \pm 11.9^{* *}$ & $82.2 \pm 4.5^{\# \#}$ & $39.5 \pm 6.1^{* *, \# \#}$ \\
\hline Liver cholesterol ( $\mathrm{mg} \mathrm{g}^{-1}$ liver) & $2.3 \pm 0.4$ & $4.4 \pm 0.7^{* *}$ & $1.0 \pm 0.6^{* *, \# \#}$ & $0.9 \pm 0.4^{* *, \# \#}$ \\
\hline Glucose concentration $\left(\mathrm{mmoll}^{-1}\right)$ & $6.7 \pm 2.1$ & $20.8 \pm 4.4^{* *}$ & $8.4 \pm 3.2^{\# \#}$ & $5.6 \pm 1.5^{\# \#}$ \\
\hline Insulin concentration $\left(\mu \mathrm{U} \mathrm{ml}^{-1}\right)$ & $22.7 \pm 16.5$ & $171.5 \pm 120.9^{* *}$ & $42.7 \pm 33.4^{\# \#}$ & $28.8 \pm 13.0^{\# \#}$ \\
\hline HOMA-IR & $7.5 \pm 3.9$ & $139.9 \pm 81.6^{* *}$ & $20.6 \pm 17.3^{\# \#}$ & $7.7 \pm 5.4^{\# \#}$ \\
\hline GOT concentration $\left(\mathrm{Ul}^{-1}\right)$ & $42.7 \pm 14.8$ & $176.3 \pm 77.9^{* *}$ & $82.2 \pm 59.5^{\#}$ & $64.8 \pm 29.6^{\#}$ \\
\hline GPT concentration $\left(\mathrm{Ul}^{-1}\right)$ & $16.8 \pm 5.0$ & $56.7 \pm 14.0^{* *}$ & $12.2 \pm 3.0^{\# \#}$ & $19.8 \pm 7.8^{\# \#}$ \\
\hline
\end{tabular}

KKAy mice were given a low-fat diet (LF), a high-fat diet (HF), HF containing 2.5\% AP (HF/AP 2.5\%) or HF containing 5.0\% AP (HF/AP 5.0\%) for 7 weeks. After measuring body weight, white adipose tissue and liver were removed and weighed, and levels of liver triglyceride and cholesterol were measured. Blood samples were also collected to measure glucose, insulin, GOT and GPT levels. HOMA-IR was calculated from glucose and insulin levels after overnight fasting. Food intake was measured once weekly. Details of the diets are given in the "Materials and Methods" section. Data represent means \pm SDs of 10 mice per group.

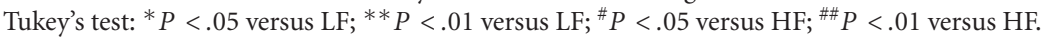

Furthermore, visceral white adipose tissue weight was significantly higher for the HF group than for the LF group. AP significantly suppressed this increase in a dose-dependent manner (Table 2).

HE staining of epididymal white adipose tissue showed that mature adipocytes for the HF group were hypertrophied, with numerous immature adipocytes in the stroma. Conversely, HF-induced hypertrophy of mature adipocytes was not seen for the HF/AP 5.0\% group, and the size of adipocytes and number of immature adipocytes were comparable to those for the LF group (Figure 1).

3.2. Liver Lipid Accumulation. Table 2 shows liver weight and liver lipid content. At the end of administration, liver weight was about 1.8 times greater for the HF group than for the LF group. In addition, liver triglyceride and cholesterol levels were significantly higher for the HF group when compared to the LF group. For both HF/AP 2.5\% and HF/AP $5.0 \%$ groups, increased liver weight and triglyceride and cholesterol accumulation were significantly suppressed.

The liver was subjected to HE staining and oil red $\mathrm{O}$ staining, and the HF group displayed large fat droplets throughout liver lobules. However, HF/AP $2.5 \%$ and HF/AP $5.0 \%$ groups showed smaller fat droplets in individual hepatocyte and fewer fat droplets throughout liver lobules, thus indicating suppression of fatty liver (Figure 2).

3.3. Plasma Glucose, Insulin, GOT and GPT Concentration. Table 2 shows fasting plasma glucose, plasma insulin, GOT and GPT. Plasma glucose and plasma insulin levels were significantly higher for the HF group than for the LF group. Conversely, plasma glucose and insulin levels for the AP groups decreased to levels similar to those for the LF group, and HOMA-IR index in the HF/AP 2.5\% and HF/AP 5.0\% groups was significantly decreased compared to the HF group. Plasma GOT and GPT, indicators of hepatopathy, were significantly higher for the HF group than for the LF group. AP administration significantly suppressed increases in GOT and GPT.

3.4. mRNA and Protein Expression in the Skeletal Muscle. Real-time RT-PCR was performed to measure the mRNA expression of energy expenditure-related genes (peroxisome proliferator-activated receptor (PPAR) $\alpha, \operatorname{PPAR} \delta$, carnitine palmitoyl-transferase 1 (CPT1), acyl CoA oxidase (ACO) and uncoupling protein 3 (UCP3)) and glucose transporter 4 (GLUT4) in skeletal muscle, an important organ for energy expenditure (Figure 3). No significant difference existed in all genes between LF and HF groups. The mRNA expression of PPAR $\alpha$ for the HF/AP $5.0 \%$ group was significantly higher (1.5 times) than that for the HF group. In addition, mRNA expression of PPAR $\delta$ for the HF/AP $2.5 \%$ and HF/AP $5.0 \%$ groups was 1.8 and 2.0 times higher when compared to the HF group. Moreover, AP significantly increased mRNA expression of CPT1, ACO and UCP3. In particular, compared to the HF group, mRNA expression of UCP3 for the HF/AP 2.5\% and HF/AP 5.0\% groups was about 2 and 3 times greater, respectively. AP administration increased mRNA expression of GLUT4 (abundantly expressed in 

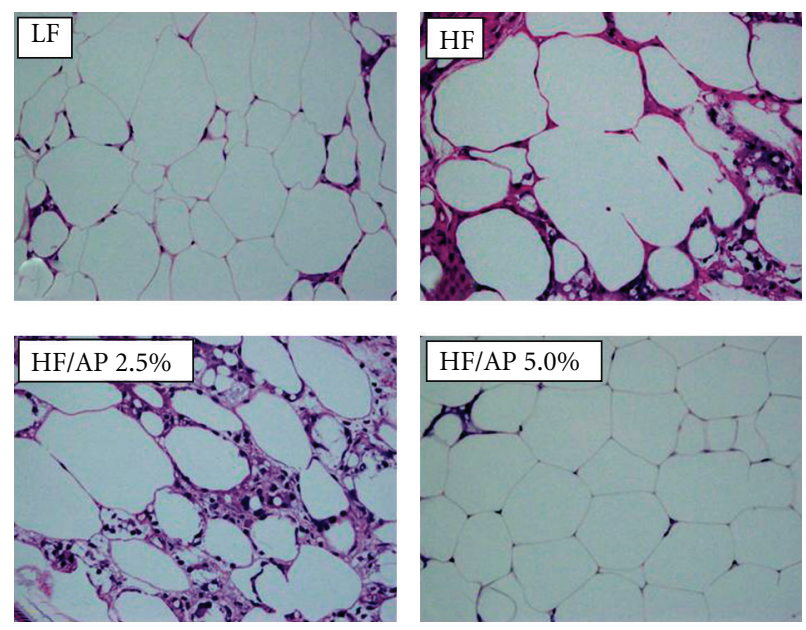

(a) HE Staining

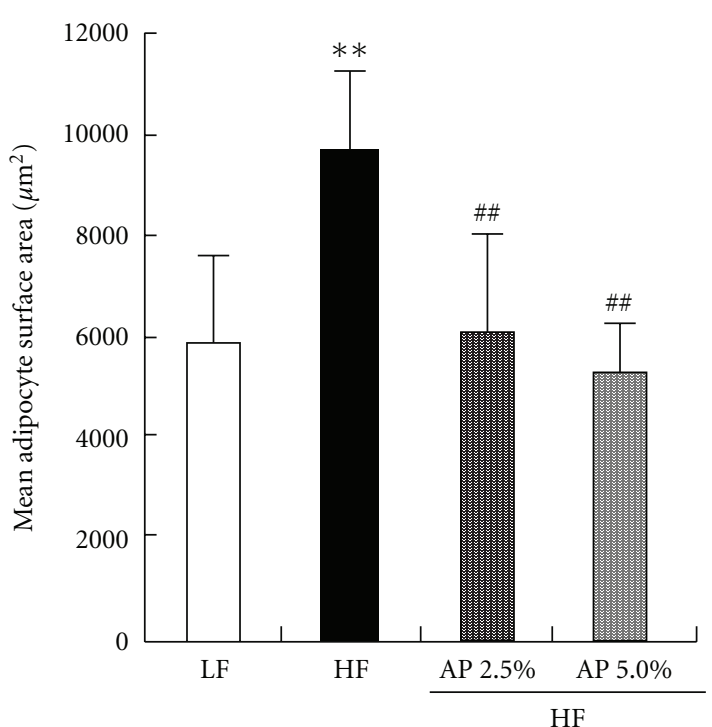

(b) Adipocyte area

FIGURE 1: Histology of epididymal adipose tissue (a) and mean adipocyte surface area (b). KKAy mice were given a LF, a HF, HF containing 2.5\% AP (HF/AP 2.5\%) or HF containing 5.0\% AP (HF/AP 5.0\%) for 7 weeks. White adipose tissue around the testis was removed, fixed in $10 \%$ neutral-buffered formalin, paraffinized and stained using HE (a). Mean surface area for epididymal white adipocytes was measured using Image J software (b). Details of the diets are given in the "Materials and Methods" section. Data represent means \pm SDs for seven sections per group. Tukey's test: ${ }^{* *} P<.01$ versus LF; ${ }^{\# \#} P<.01$ versus HF.
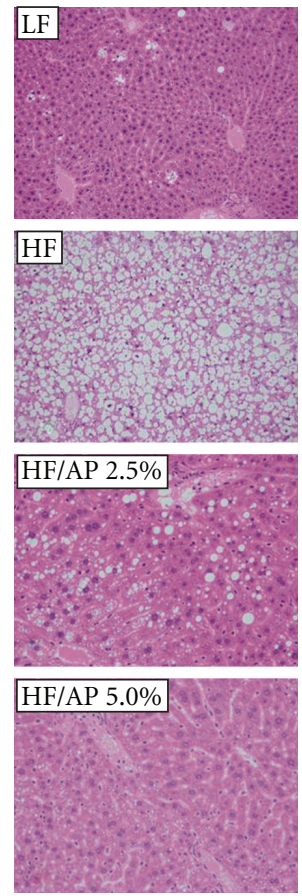

(a) HE Staining
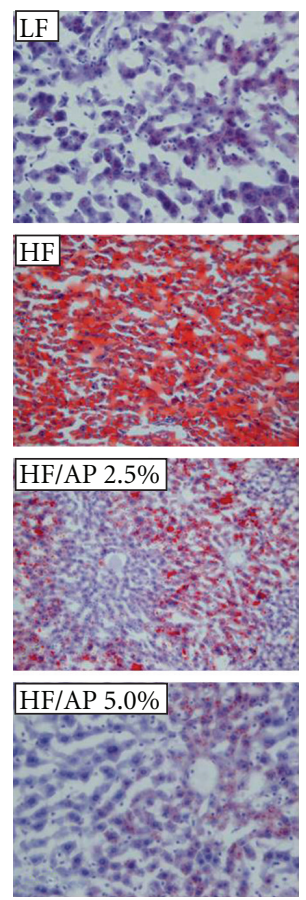

(b) Oil red O staining

FIgURE 2: Representative histological sections of liver stained with HE (a) or oil red O (b). KKAy mice were given a LF, a HF, HF containing $2.5 \%$ AP (HF/AP $2.5 \%$ ) or HF containing $5.0 \%$ AP (HF/AP 5.0\%) for 7 weeks. The liver was removed, fixed in $10 \%$ neutral-buffered formalin, paraffinized and stained using HE (a). A cryostat was also used to prepare tissue sections for staining with oil red $\mathrm{O}(\mathrm{b})$. Details of the diets are given in the "Materials and Methods" section.

skeletal muscle), and mRNA expression of GLUT4 for the HF/AP 5.0\% group was about double that for the HF group.

Protein expressions of CPT1, ACO and UCP3 were quantified by western blotting, and AP administration significantly increased the expression of all proteins (Figure 4). These increases also correlated to increased mRNA expressions.

3.5. $m R N A$ Expression in the Liver. In the liver, expressions of fatty acid synthesis-related genes (sterol regulatory elementbinding protein (SREBP)-1c, acetyl-CoA carboxylase (ACC) and fatty acid synthase (FAS)), a fatty acid decompositionrelated gene $(\operatorname{PPAR} \alpha)$ and fat intake-related genes (PPAR $\gamma$ and lipoprotein lipase (LPL)) were measured by real-time RT-PCR (Figure 5). The mRNA expressions of SREBP-1c, ACC and FAS were significantly lower for HF/AP 2.5\% and HF/AP 5.0\% groups than for the HF group. In addition, mRNA expression of PPAR $\alpha$ was significantly higher for the HF/AP 2.5\% and HF/AP 5.0\% groups than for the HF group. Furthermore, mRNA expressions of PPAR $\gamma$ and LPL, which are related to liver fat accumulation, were significantly lower when compared to the HF group.

3.6. mRNA Expression in White Adipose Tissue. The mRNA expressions of adipocytokines (adiponectin and tumor necrosis factor (TNF)- $\alpha$ ), which are produced in white adipose tissue and play important roles in obesity and diabetes, and PPAR $\gamma$ were measured by real-time RT-PCR (Figure 6). The results showed that mRNA expression of adiponectin was significantly lower for the HF group than for the LF group, while mRNA expression of TNF- $\alpha$ was significantly 


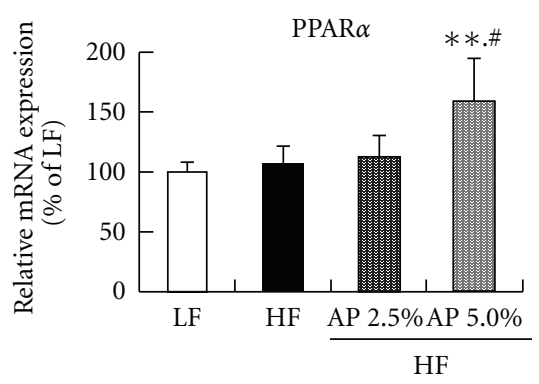

(a)

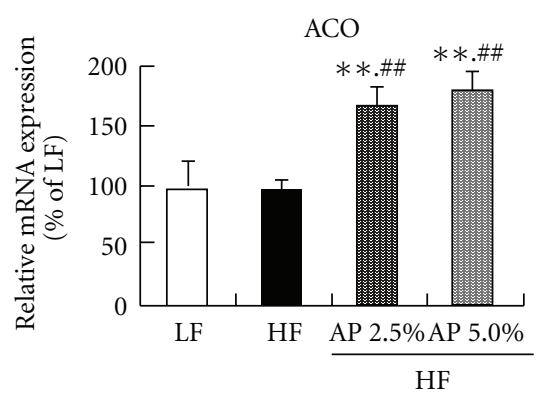

(d)

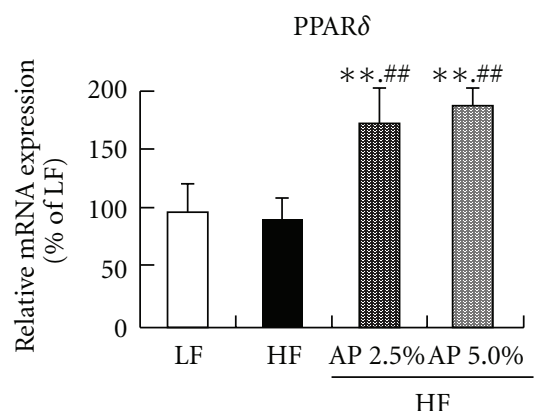

(b)

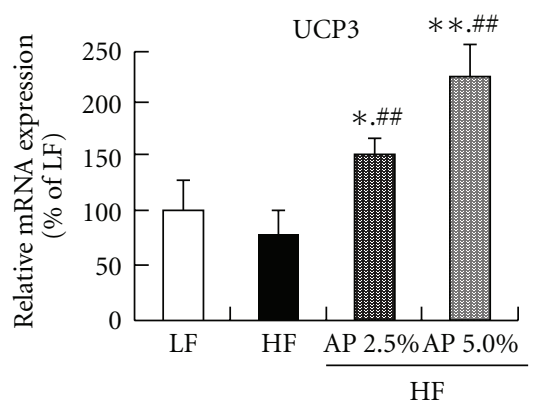

(e)

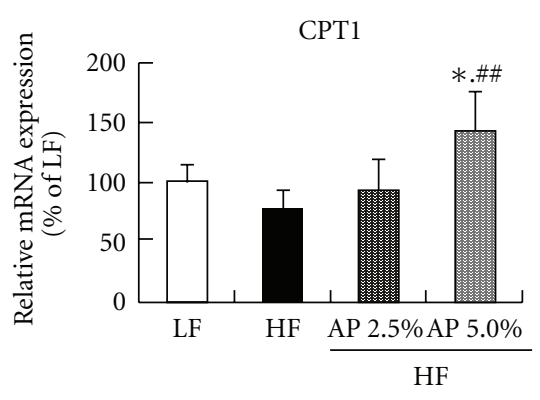

(c)

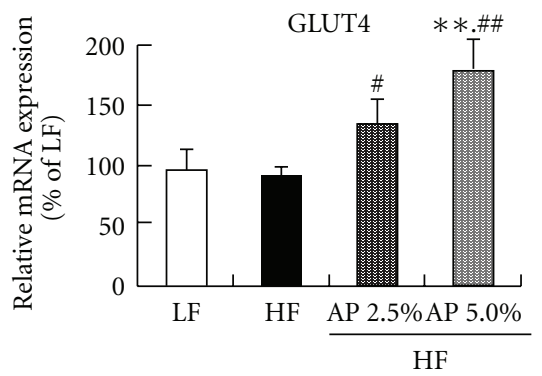

(f)

FIGURE 3: Effect of acacia polyphenol on mRNA expression in skeletal muscle. KKAy mice were given a LF, HF, HF containing 2.5\% AP (HF/AP 2.5\%) or HF containing 5.0\% AP (HF/AP 5.0\%) for 7 weeks. Skeletal muscle was removed, and mRNA expressions were measured using real-time RT-PCR, using $\beta$-actin as a housekeeping gene. All mRNA expressions are given as percentages compared to the LF group $(100 \%)$. Details of the diets are given in the "Materials and Methods" section. Data represent means \pm SDs for six mice per group. Tukey's test: ${ }^{*} P<.05$ versus LF; ${ }^{* *} P<.01$ versus $L F ;{ }^{*} P<.05$ versus $H F ;{ }^{\# \#} P<.01$ versus $H F$.

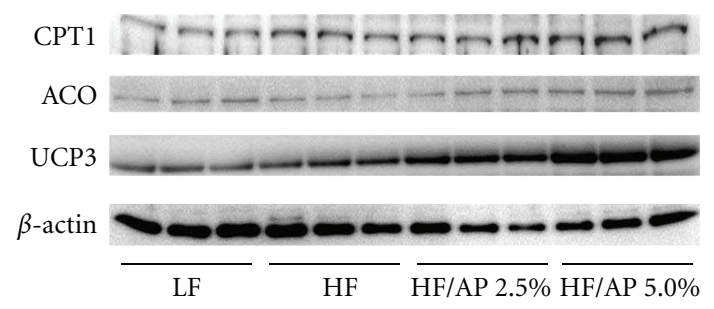

(a)

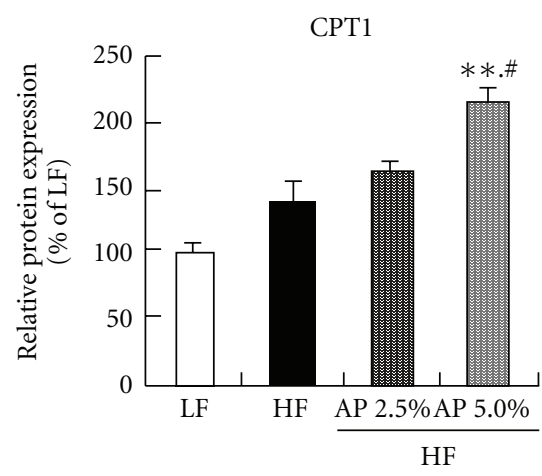

(b)

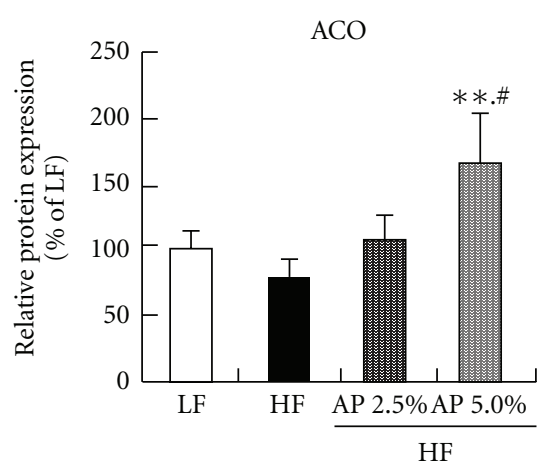

(c)

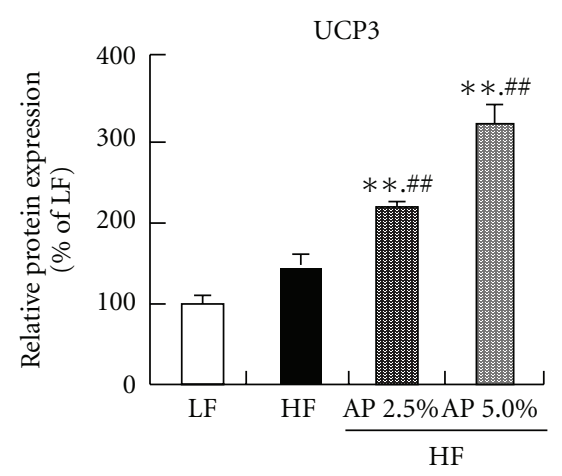

(d)

FIGURE 4: Effect of acacia polyphenol on protein expression of CPT1, ACO and UCP3 in skeletal muscle. KKAy mice were given a LF, a HF, HF containing 2.5\% AP (HF/AP 2.5\%) or HF containing 5.0\% AP (HF/AP 5.0\%) for 7 weeks. The skeletal muscle was removed, and protein expression was measured by western blotting, using $\beta$-actin as a housekeeping gene. All protein expressions are given as percentages compared to the LF group (100\%). Details of the diets are given in the "Materials and Methods" section. Data represent means \pm SDs for six mice per group. Tukey's test: ${ }^{* *} P<.01$ versus LF; ${ }^{\#} P<.05$ versus $H F$; ${ }^{\#} P<.01$ versus HF. 


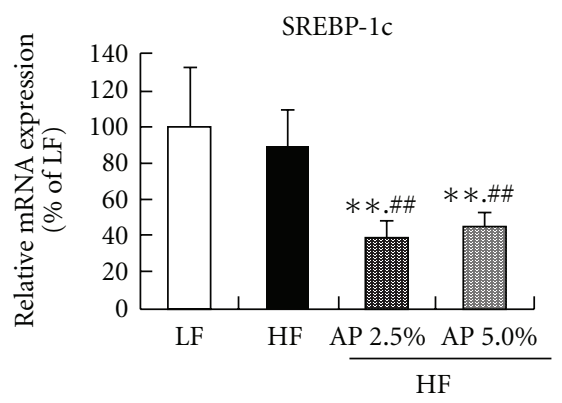

(a)

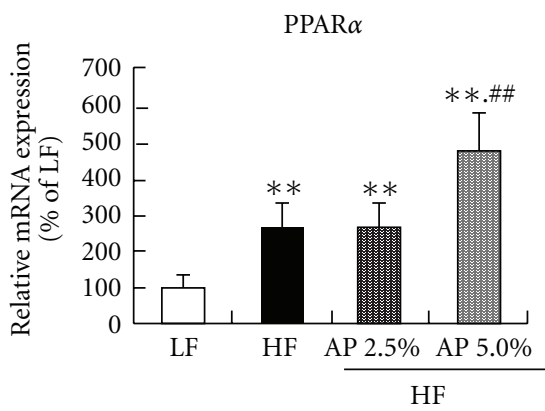

(d)

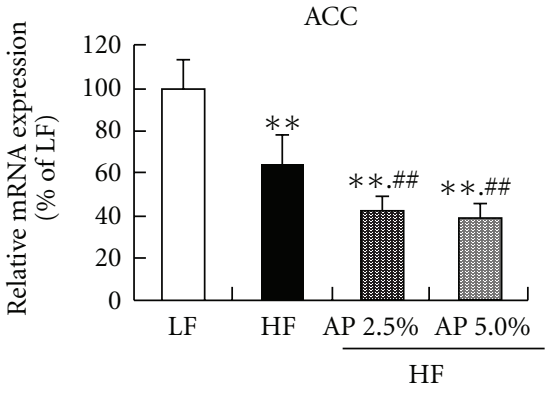

(b)

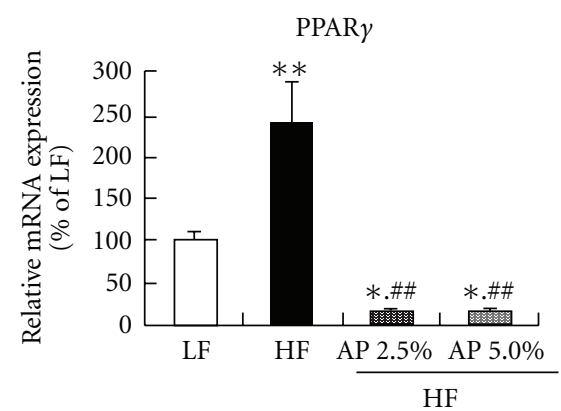

(e)

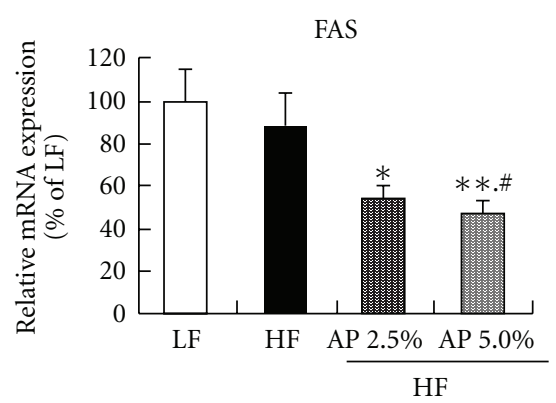

(c)

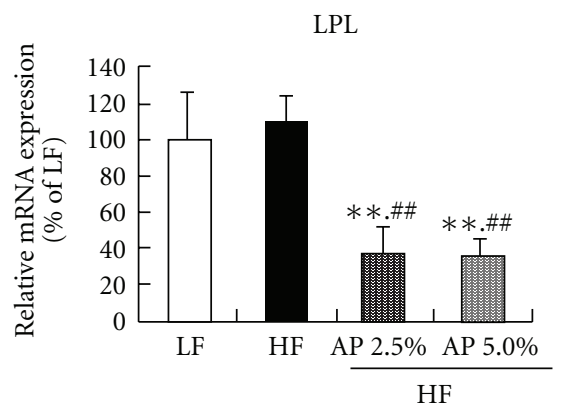

(f)

FIGURE 5: Effect of acacia polyphenol on mRNA expression in the liver. KKAy mice were given a LF, a HF, HF containing 2.5\% AP (HF/AP 2.5\%) or HF containing 5.0\% AP (HF/AP 5.0\%) for 7 weeks. The liver was removed and mRNA expression was measured by real-time RT-PCR using $\beta$-actin as a housekeeping gene. All mRNA expressions are given as percentages compared to the LF group (100\%). Details of the diets are given in the "Materials and Methods" section. Data represent means \pm SDs for six mice per group. Tukey's test: ${ }^{*} P<.05$ versus LF; ${ }^{* *} P<.01$ versus $L F ;{ }^{\#} P<.05$ versus HF; ${ }^{\# \#} P<.01$ versus HF.

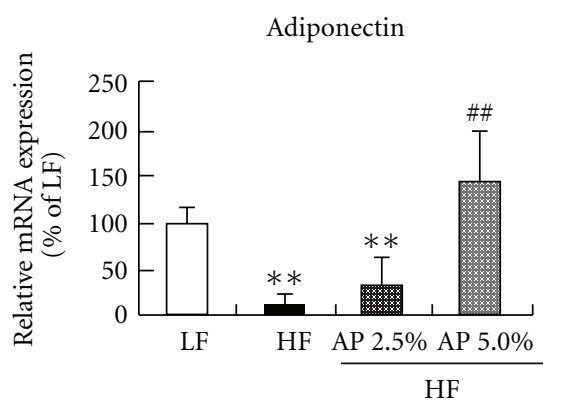

(a)

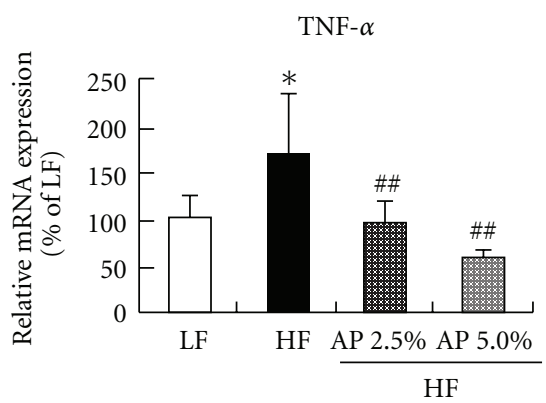

(b)

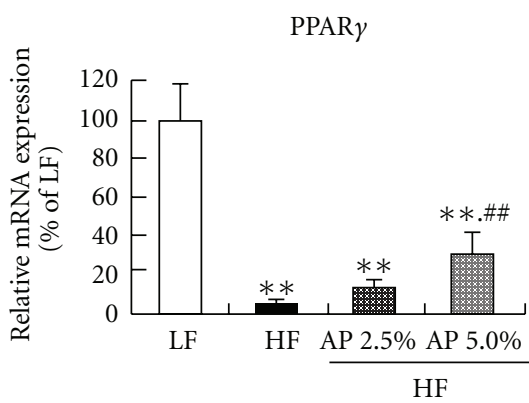

(c)

FIGURE 6: Effect of acacia polyphenol on mRNA expression in epididymal white adipose tissue. KKAy mice were given a LF, HF, HF containing 2.5\% AP (HF/AP 2.5\%) or HF containing 5.0\% AP (HF/AP 5.0\%) for 7 weeks. White adipose tissue around the testis was removed, and mRNA expression was measured by real-time RT-PCR, using $\beta$-actin as a housekeeping gene. All mRNA expressions are given as percentages compared to the LF group (100\%). Details of diets are given in the "Materials and Methods" section. Data represent means \pm SDs for six mice per group. Tukey's test: ${ }^{*} P<.05$ versus LF; ${ }^{* *} P<.01$ versus LF; ${ }^{\#} P<.01$ versus HF.

higher. Conversely, mRNA expression of adiponectin was significantly higher for the HF/AP $2.5 \%$ and HF/AP $5.0 \%$ groups in a dose-dependent manner when compared to the HF group, but mRNA expression of TNF- $\alpha$ was significantly lower. In particular, expression of TNF- $\alpha$ was significantly lower for the HF/AP 5.0\% group when compared to the LF group. The mRNA expression of PPAR $y$ for the HF group was significantly lower (about 90\% lower) compared to the LF group. AP administration significantly accentuated this decrease in mRNA expression in a dose-dependent manner.

\section{Discussion}

The anti-obesity effects of $\mathrm{AP}$, a new polyphenol, were investigated using KKAy mice as a model of obese type-II diabetes. When fed a normal diet, KKAy mice develop obesity and type-II diabetes by 12-weeks old [31], and these mice are thus widely used for research into obesity and diabetes $[32,33]$. In the present study, lard was administered to 6week-old KKAy mice for 7 weeks to induce severe obesity and diabetes and the effects of AP were evaluated. Lard is widely 


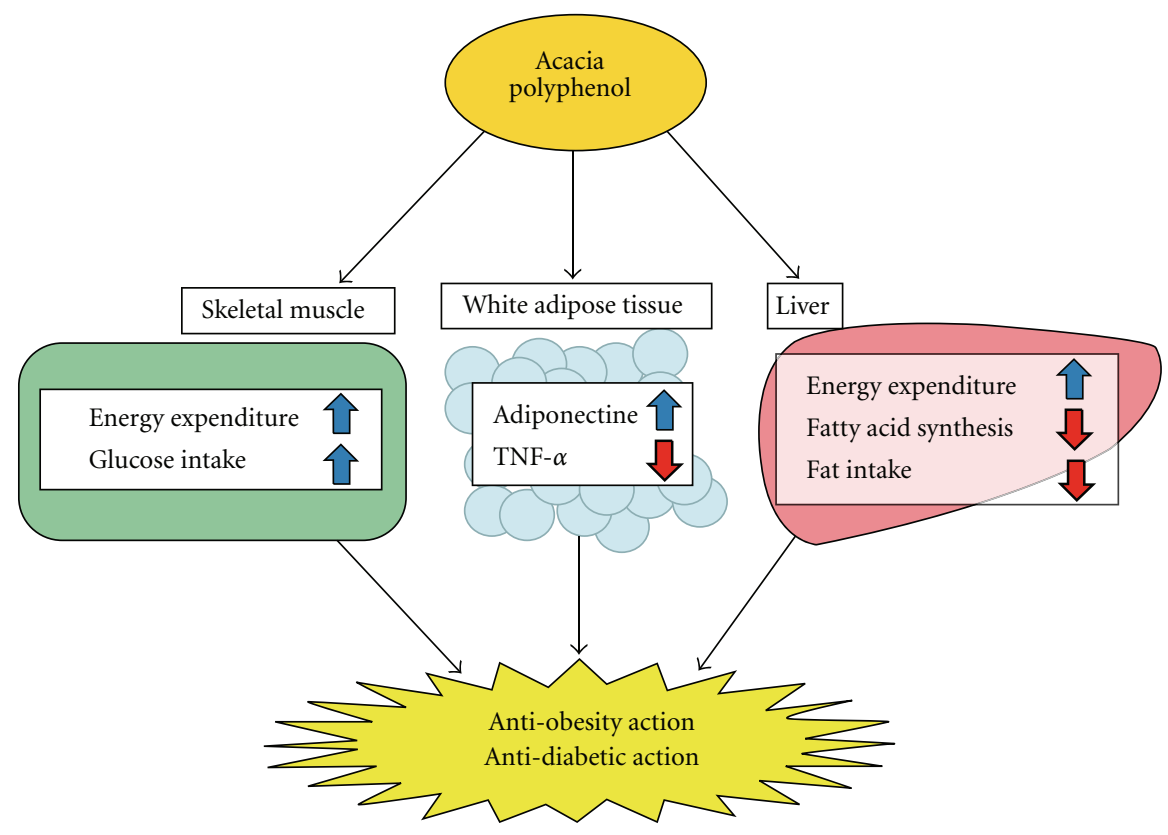

FIgURE 7: Hypothetical mechanisms of anti-obesity/diabetic actions of acacia polyphenol.

used in studies on obesity and diabetes [34, 35]. AP was found to significantly suppress increases in body weight and white adipose tissue weight, showing anti-obesity actions (Table 2, Figure 1). HF also increased liver fat accumulation and induced fatty liver, but AP administration lowered fat accumulation, clarifying that AP suppresses fatty liver (Table 2, Figure 2). Furthermore, measurements of plasma GOT and GPT clarified that AP suppressed fatty liverinduced hepatopathy (Table 2). Plasma glucose and insulin levels were significantly higher for the HF group than for the LF group, and severe type II diabetes was induced. AP suppressed these increases in plasma glucose and insulin levels. The HOMA-IR index, a simpler method to measure insulin sensitivity usually used in clinical and animal studies [22, 36], was significantly decreased in AP-treated groups compared to the HF group, indicating that AP reduced hyperglycemia and hyperinsulinemia (Table 2). These findings clarify that AP suppresses obesity and diabetes caused by a high-fat diet.

Obesity is caused by low energy expenditure and increased fatty acid synthesis from carbohydrates and fat intake by organs. Therefore, as well as the effects of AP on the expression of energy expenditure-related genes in skeletal muscle and liver, effects on the expression of genes related to fatty acid synthesis and fat intake in the liver were investigated.

In skeletal muscle, 7 weeks of AP administration significantly increased mRNA and protein expressions of ACO, CPT1 ( $\beta$-oxidation enzymes) and UCP3 (uncoupling protein) compared to the HF group (Figures 3 and 4). AP administration also increased mRNA expression of PPAR $\alpha$ and $\operatorname{PPAR} \delta$ (nuclear receptors). The mRNA expression of $\operatorname{PPAR} \alpha$ increased not only in skeletal muscle, but also in liver. Activation and elevation of $\operatorname{PPAR} \alpha$ and $\operatorname{PPAR} \delta$ expression is known to increase expression of CPT1, ACO and UCP3 to elevate energy expenditure, subsequently resulting in anti-obesity actions [37-40]. This suggests that AP acts on skeletal muscle and liver to increase energy expenditure. Furthermore, AP decreased mRNA expression of ACC and FAS, the rate-limiting enzymes of fatty acid synthesis in the liver, and mRNA expression of SREBP-1c, which controls the expression of these enzymes [41]. Furthermore, AP lowered the mRNA expression of PPAR $\gamma$ and LPL, which are related to fat intake by the liver (Figure 5). Reduced expressions of fatty acid synthetase [9], PPAR $\gamma[42,43]$ and LPL [44] in the liver suppress the onset of obesity and fatty liver. These findings indicate that the anti-obesity actions of AP are due to increased expression of energy expenditure-related genes in skeletal muscle and liver and decreased fatty acid synthesis and fat intake in the liver.

Insulin resistance can be generated by decreased adiponectin secretion and increased TNF- $\alpha$ secretion [45, 46]. AP increased mRNA expression of adiponectin and decreased mRNA expression of TNF- $\alpha$ in white adipose tissue (Figure 6). In white adipose tissue, AP administration significantly increased (by about 5-fold) the mRNA expression of $\operatorname{PPAR} \gamma$, which facilitates the expression of adiponectin [47]. Furthermore, AP significantly increased the mRNA expression of GLUT4 in skeletal muscle (Figure 3). GLUT4 is one of the glucose transporters that are frequently expressed in skeletal muscle, and an increase in GLUT4 expression has been known to reduce insulin resistance [48]. AP thus reduces hyperglycemia and hyperinsulinemia, not simply through alleviated obesity, but through increased adiponectin secretion and suppressed TNF- $\alpha$ secretion in white adipose tissue, and increased GLUT4 expression in skeletal muscle.

Various pharmacological actions of polyphenols have been reported. The AP used in the present study acted on skeletal muscle, liver and white adipose tissue and was shown to possess anti-obesity and anti-diabetic actions (Figure 7). 
While many studies have described plant extracts exhibiting anti-obesity and anti-diabetic actions, to the best of our knowledge, none have demonstrated anti-obesity and antidiabetic actions via the modification of energy expenditurerelated genes in skeletal muscle. In recent years, selective $\operatorname{PPAR} \delta$ agonists, such as synthetic GW501516, have been shown to suppress body weight increase and reduce insulin resistance in obese diabetic mice $[37,38]$. The present study suggests that AP is a plant extract with a novel mechanism of action with skeletal muscle as an active site.

\section{Conclusion}

In KKAy mice with high-fat diet-induced obesity, the antiobesity actions of AP appear attributable to increased expression of energy expenditure-related genes in skeletal muscle and liver, and decreased fatty acid synthesis and fat intake in the liver. AP also reduced hyperglycemia and hyperinsulinemia by increasing adiponectin secretion and suppressing TNF- $\alpha$ secretion by white adipocytes, and elevating the expression of GLUT4 in skeletal muscle in addition to reducing obesity. In the future, AP seems to offer potential as a plant extract that is useful for alleviating metabolic syndrome.

\section{References}

[1] K. N. Singh, R. K. Mittal, and K. C. Barthwal, "Hypoglycaemic activity of Acacia catechu, Acacia suma, and Albizzia odoratissima seed diets in normal albino rats," Indian Journal of Medical Research, vol. 64, no. 5, pp. 754-757, 1976.

[2] A. Wadood, N. Wadood, and S. A. W. Shah, "Effects of Acacia arabica and caralluma edulis on blood glucose levels of normal and alloxan diabetic rabbits," Journal of the Pakistan Medical Association, vol. 39, no. 8, pp. 208-212, 1989.

[3] D. G. Roux and E. A. Maihs, "Condensed tannins. 3.

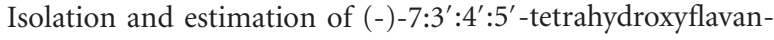
3-ol, (+)-catechin and (+)-gallocatechin from black-wattlebark extract,” Biochemical Journal, vol. 74, pp. 44-49, 1960.

[4] D. G. Roux and E. Paulus, "Condensed tannins. 7. Isolation of (-)-7:3':4' -trihydroxyflavan-3-ol [(-)-fisetinidol], a naturally occurring catechin from black-wattle heartwood," Biochemical Journal, vol. 78, pp. 120-123, 1961.

[5] D. G. Roux, E. A. Maihs, and E. Paulus, "Condensed tannins. 9. Distribution of flavonoid compounds in the heartwoods and barks of some interrelated wattles," Biochemical Journal, vol. 78, pp. 834-839, 1961.

[6] S. E. Drewes and D. G. Roux, "Condensed tannins. 15. Interrelationships of flavonoid components in wattle-bark extract," Biochemical Journal, vol. 87, pp. 167-172, 1963.

[7] L.-K. Han, T. Takaku, J. Li, Y. Kimura, and H. Okuda, "Antiobesity action of oolong tea," International Journal of Obesity, vol. 23, no. 1, pp. 98-105, 1999.

[8] T. Murase, A. Nagasawa, J. Suzuki, T. Hase, and I. Tokimitsu, "Beneficial effects of tea catechins on diet-induced obesity: stimulation of lipid catabolism in the liver," International Journal of Obesity, vol. 26, no. 11, pp. 1459-1464, 2002.

[9] Y. Ohta, M. Sami, T. Kanda, K. Saito, K. Osada, and H. Kata, "Gene expression analysis of the anti-obesity effect by apple polyphenols in rats fed a high fat diet or a normal diet," Journal of Oleo Science, vol. 55, pp. 305-314, 2006.
[10] A. Ruzaidi, I. Amin, A. G. Nawalyah, M. Hamid, and H. A. Faizul, "The effect of Malaysian cocoa extract on glucose levels and lipid profiles in diabetic rats," Journal of Ethnopharmacology, vol. 98, no. 1-2, pp. 55-60, 2005.

[11] G. Klein, J. Kim, K. Himmeldirk, Y. Cao, and X. Chen, "Antidiabetes and anti-obesity activity of Lagerstroemia speciosa," Evidence-Based Complementary and Alternative Medicine, vol. 4, no. 4, pp. 401-407, 2007.

[12] T. Akase, T. Shimada, Y. Harasawa et al., "Preventive effects of Salacia reticulate on obesity and metabolic dixorders in TSOD mice," Evidence-Based Complementary and Alternative Medicine, 2009.

[13] S. E. Chuang, M. L. Kuo, C. H. Hsu et al., "Curcumincontaining diet inhibits diethylnitrosamine-induced murine hepatocarcinogenesis," Carcinogenesis, vol. 21, no. 2, pp. 331335, 2000.

[14] G. Peng, D. A. Dixon, S. J. Muga, T. J. Smith, and M. J. Wargovich, "Green tea polyphenol (-)-epigallocatechin-3-gallate inhibits cyclooxygenase-2 expression in colon carcinogenesis," Molecular Carcinogenesis, vol. 45, no. 5, pp. 309-319, 2006.

[15] T. Enomoto, Y. Nagasako-Akazome, T. Kanda, M. Ikeda, and Y. Dake, "Clinical effects of apple polyphenols on persistent allergic rhinitis: a randomized double-blind placebo-controlled parallel arm study," Journal of Investigational Allergology and Clinical Immunology, vol. 16, no. 5, pp. 283-289, 2006.

[16] N. J. Cutting, "The development and application of speciality wattle extracts," Journal of the Society of Leather Technologies and Chemists, vol. 81, no. 3, pp. 89-93, 1997.

[17] E. Stiasny, "Die einwiirkung von formaldehyde auf gerbstoffe," Der Gerber, vol. 740, pp. 186-188, 1905.

[18] Y. Yazaki, Z. Guangcheng, and S. D. Searle, "Extractives Yields and polyflavanoid contents of Acacia mearnsii Barks in Australia," Australian Forestry, vol. 53, pp. 148-53, 1990.

[19] Y. Yazaki, R. Gu, Y. Lin, W. Chen, and N. K. Nguyen, "Analyses of black wattle (Acacia mearnsii) tannins-relationships among the hide-powder, the Stiasny and the ultra-violet (UV) methods," Holzforschung, vol. 47, pp. 57-61, 1993.

[20] D. G. Roux and S. R. Evelyn, "Condensed tannins. I. A study of complex leucoanthocyanins present in condensed tannins," Biochemical Journal, vol. 69, pp. 530-538, 1958.

[21] D. G. Roux and S. R. Evelyn, "The correlation between structure and paper chromatographic behaviour of some flavonoid compounds and tannins," Journal of Chromatography A, vol. 1, pp. 537-544, 1958.

[22] D. R. Matthews, J. P. Hosker, A. S. Rudenski, B. A. Naylor, D. F. Treacher, and R. C. Turner, "Homeostasis model assessment: insulin resistance and beta-cell function from fasting plasma glucose and insulin concentrations in man," Diabetologia, vol. 28, pp. 412-419, 1985.

[23] L.-K. Han, Y. Kimura, and H. Okuda, "Reduction in fat storage during chitin-chitosan treatment in mice fed a high-fat diet," International Journal of Obesity, vol. 23, no. 2, pp. 174-179, 1999.

[24] S. H. Park, S. K. Ko, and S. H. Chung, "Euonymus alatus prevents the hyperglycemia and hyperlipidemia induced by high-fat diet in ICR mice," Journal of Ethnopharmacology, vol. 102, no. 3, pp. 326-335, 2005.

[25] K. Tsuchiya, H. Sakai, N. Suzuki et al., "Chronic blockade of nitric oxide synthesis reduces adiposity and improves insulin resistance in high fat-induced obese mice," Endocrinology, vol. 148, no. 10, pp. 4548-4556, 2007. 
[26] N. H. Rogers, J. W. P. Li, K. J. Strissel, M. S. Obin, and A. S. Greenberg, "Reduced energy expenditure and increased inflammation are early events in the development of ovariectomy-induced obesity," Endocrinology, vol. 150, no. 5, pp. 2161-2168, 2009.

[27] F. Felipe, M. L. Bonet, J. Ribot, and A. Palou, "Up-regulation of muscle uncoupling protein 3 gene expression in mice following high fat diet, dietary vitamin A supplementation and acute retinoic acid-treatment," International Journal of Obesity, vol. 27, no. 1, pp. 60-69, 2003.

[28] S. H. Cha, Z. Hu, S. Chohnan, and M. D. Lane, "Inhibition of hypothalamic fatty acid synthase triggers rapid activation of fatty acid oxidation in skeletal muscle," Proceedings of the National Academy of Sciences of the United States of America, vol. 102, no. 41, pp. 14557-14562, 2005.

[29] O. H. Lowry, N. J. Rosebrough, A. L. Farr, and R. J. Randall, "Protein measurement with the Folin phenol reagent," The Journal of Biological Chemistry, vol. 193, pp. 265-275, 1951.

[30] U. K. Laemmli, "Cleavage of structural proteins during the assembly of the head of bacteriophage T4," Nature, vol. 227, no. 5259, pp. 680-685, 1970.

[31] K. Hayashi and M. Ito, "Antidiabetic action of low molecular weight chitosan in genetically obese diabetic KK-Ay mice," Biological and Pharmaceutical Bulletin, vol. 25, no. 2, pp. 188 192, 2002.

[32] A. Tsuchida, T. Yamauchi, S. Takekawa et al., "Peroxisome proliferator-activated receptor $(\mathrm{PPAR}) \pm$ activation increases adiponectin receptors and reduces obesity-related inflammation in adipose tissue: comparison of activation of PPAR \pm , $\mathrm{PPAR}^{3}$, and their combination," Diabetes, vol. 54, no. 12, pp. 3358-3370, 2005.

[33] R. Vianna, A. Brault, L. C. Martineau, R. Couture, J. T. Arnason, and P. S. Haddad, "In vivo anti-diabetic activity of the ethanolic crude extract of Sorbus decora C.K.Schneid. (Rosacea): a medical plant used by Canadian james bay cree nations to treat symptoms related to diabetes," Evidence-Based Complementary and Alternative Medicine, 2009.

[34] M. G. Dube, E. Beretta, H. Dhillon, N. Ueno, P. S. Kalra, and S. P. Kalra, "Central leptin gene therapy blocks high-fat dietinduced weight gain, hyperleptinemia, and hyperinsulinemia: increase in serum ghrelin levels," Diabetes, vol. 51, no. 6, pp. 1729-1736, 2002.

[35] A. L. Hildebrandt, D. M. Kelly-Sullivan, and S. C. Black, "Antiobesity effects of chronic cannabinoid CB1 receptor antagonist treatment in diet-induced obese mice," European Journal of Pharmacology, vol. 462, no. 1-3, pp. 125-132, 2003.

[36] Y. Sasaki, W. Suzuki, T. Shimada et al., "Dose dependent development of diabetes mellitus and non-alcoholic steatohepatitis in monosodium glutamate-induced obese mice," Life Sciences, vol. 85, no. 13-14, pp. 490-498, 2009.

[37] T. Tanaka, J. Yamamoto, S. Iwasaki et al., "Activation of peroxisome proliferator-activated receptor $\delta$ induces fatty acid $\beta$-oxidation in skeletal muscle and attenuates metabolic syndrome," Proceedings of the National Academy of Sciences of the United States of America, vol. 100, no. 26, pp. 15924-15929, 2003.

[38] Y.-X. Wang, C.-L. Zhang, R. T. Yu et al., "Regulation of muscle fiber type and running endurance by PPAR $\delta$," PLoS Biology, vol. 2, no. 10, article e294, 2004.

[39] F. Villarroya, R. Iglesias, and M. Giralt, "PPARs in the control of uncoupling proteins gene expression," PPAR Research, vol. 2007, Article ID 74364, 12 pages, 2007.
[40] M. J. Yoon, G. Y. Lee, J.-J. Chung, Y. H. Ahn, S. H. Hong, and J. B. Kim, "Adiponectin increases fatty acid oxidation in skeletal muscle cells by sequential activation of AMP-activated protein kinase, p38 mitogen-activated protein kinase, and peroxisome proliferator-activated receptoralpha," Diabetes, vol. 55, no. 9, pp. 2562-2570, 2006.

[41] H. Guillou, P. G. Martin, and T. Pineau, "Transcriptional regulation of hepatic fatty acid metabolism," Sub-Cellular Biochemistry, vol. 49, pp. 3-47, 2008.

[42] M. Inoue, T. Ohtake, W. Motomura et al., "Increased expression of PPAR $\gamma$ in high fat diet-induced liver steatosis in mice," Biochemical and Biophysical Research Communications, vol. 336, no. 1, pp. 215-222, 2005.

[43] T. Tanaka, H. Masuzaki, K. Ebihara et al., "Transgenic expression of mutant peroxisome proliferator-activated receptor $\gamma$ in liver precipitates fasting-induced steatosis but protects against high-fat diet-induced steatosis in mice," Metabolism, vol. 54, no. 11, pp. 1490-1498, 2005.

[44] J. K. Kim, J. J. Fillmore, Y. Chen et al., "Tissue-specific overexpression of lipoprotein lipase causes tissue-specific insulin resistance," Proceedings of the National Academy of Sciences of the United States of America, vol. 98, no. 13, pp. 7522-7527, 2001.

[45] T. Kadowaki, T. Yamauchi, N. Kubota, K. Hara, K. Ueki, and $\mathrm{K}$. Tobe, "Adiponectin and adiponectin receptors in insulin resistance, diabetes, and the metabolic syndrome," Journal of Clinical Investigation, vol. 116, no. 7, pp. 1784-1792, 2006.

[46] S. E. Borst, "The role of TNF- $\alpha$ in insulin resistance," Endocrine, vol. 23, no. 2-3, pp. 177-182, 2004.

[47] M. Iwaki, M. Matsuda, N. Maeda et al., "Induction of adiponectin, a fat-derived antidiabetic and antiatherogenic factor, by nuclear receptors," Diabetes, vol. 52, no. 7, pp. 16551663, 2003.

[48] A. Zorzano, M. Palacín, and A. Gumà, "Mechanisms regulating GLUT4 glucose transporter expression and glucose transport in skeletal muscle," Acta Physiologica Scandinavica, vol. 183, no. 1, pp. 43-58, 2005. 


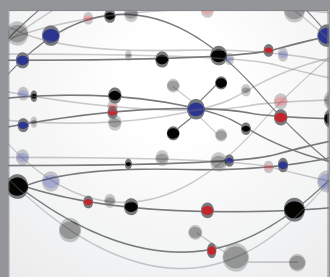

The Scientific World Journal
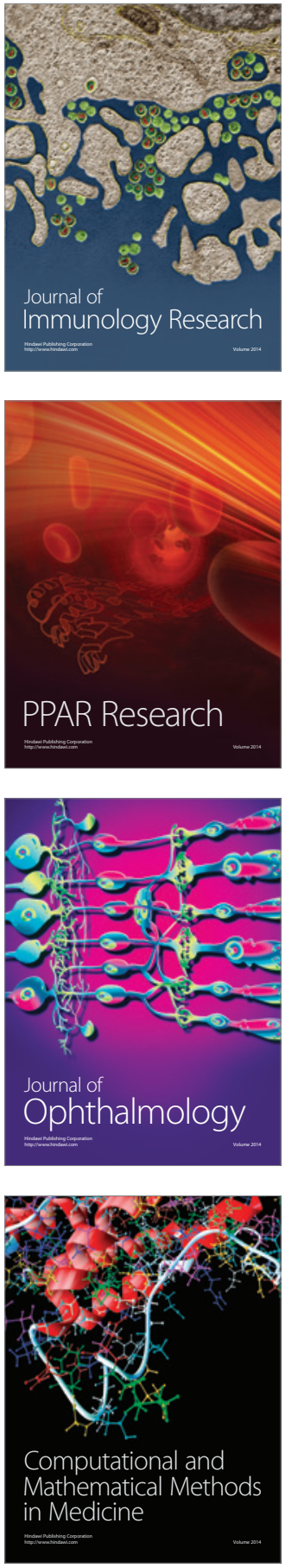

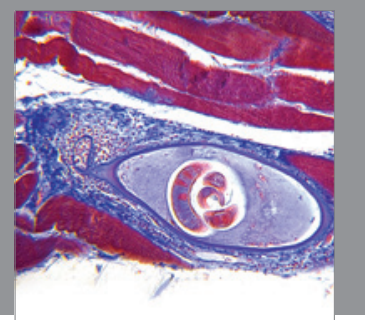

Gastroenterology

Research and Practice
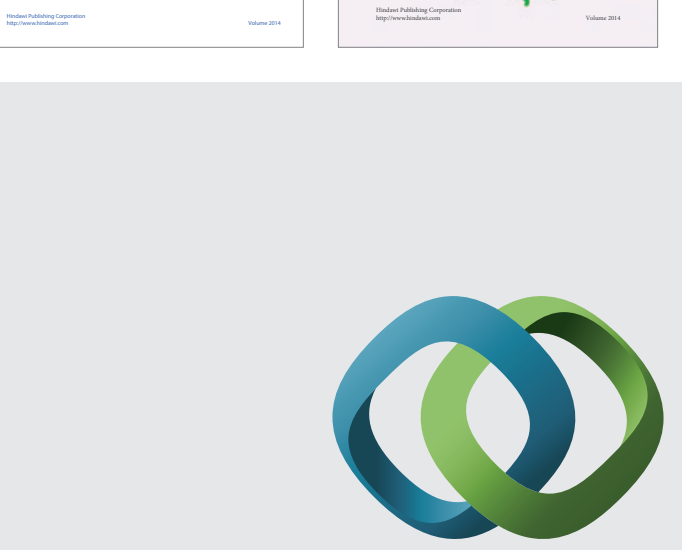

\section{Hindawi}

Submit your manuscripts at

http://www.hindawi.com
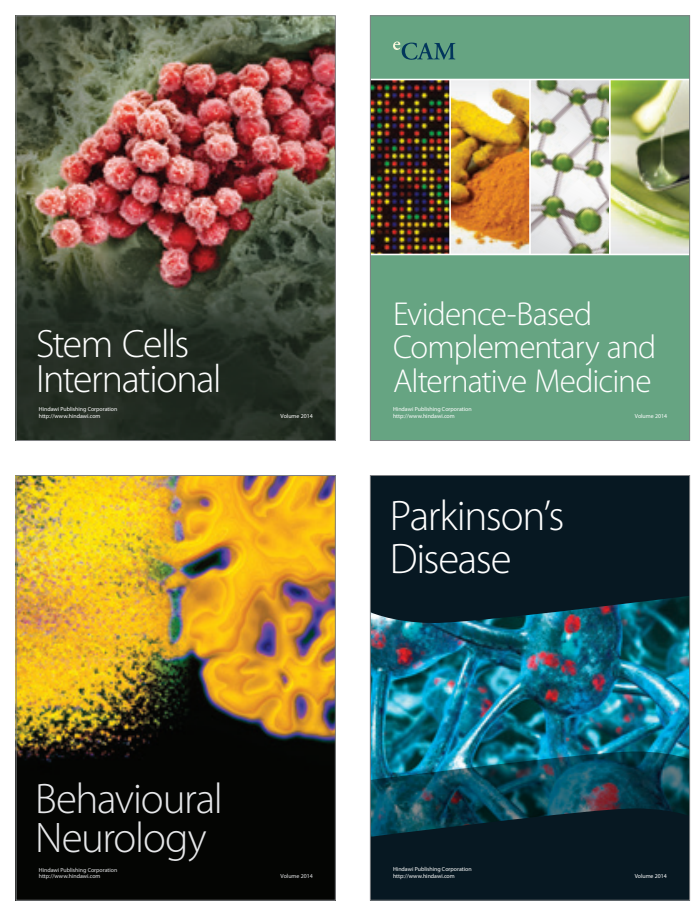

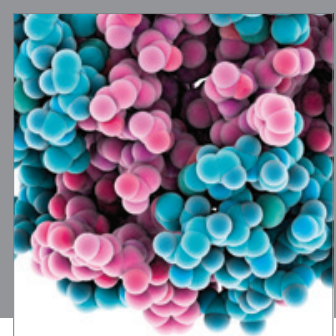

Journal of
Diabetes Research

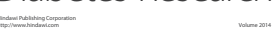

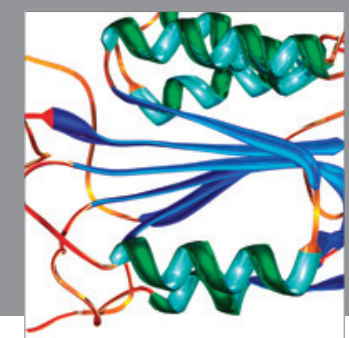

Disease Markers
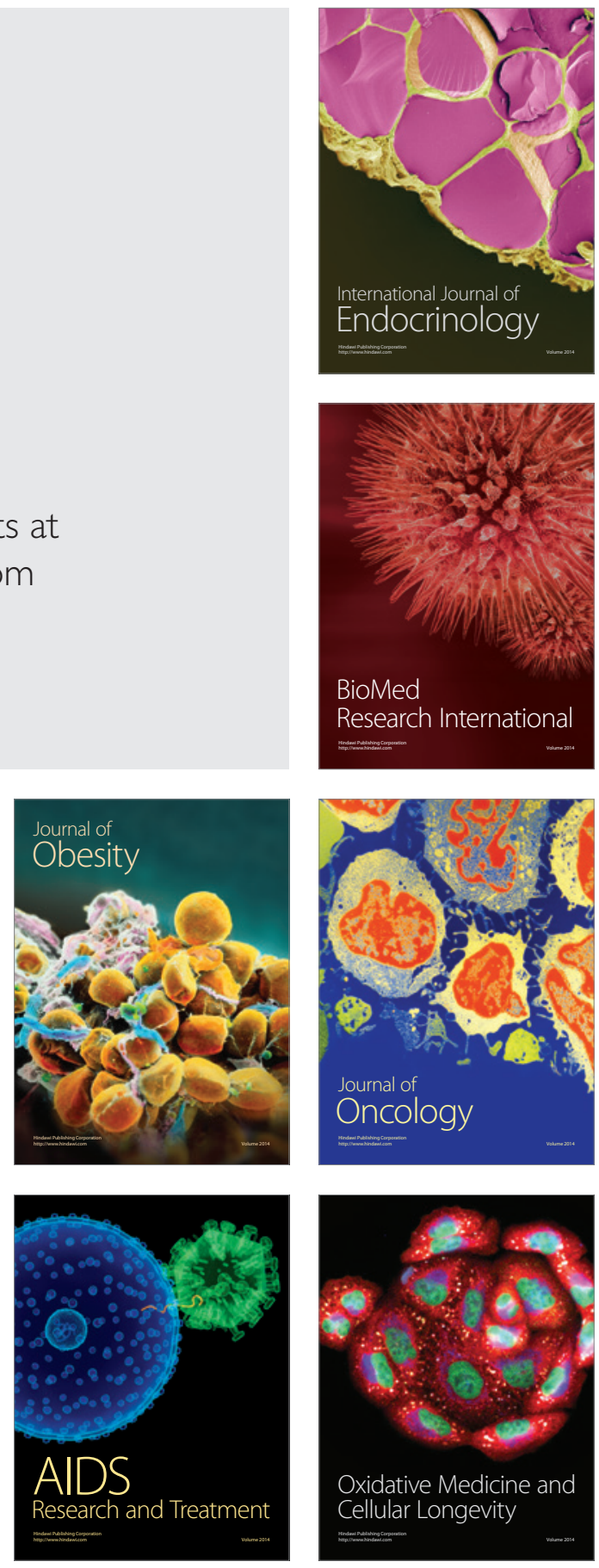